\title{
PERANAN LITERASI AKUNTANSI BAGI PENDIDIKAN KEWIRAUSAHAAN DALAM MEMAJUKAN PEMBANGUNAN EKONOMI NASIONAL
}

\author{
Budianto Tedjasukmana ${ }^{1}$, P. Julius F. Nagel ${ }^{2}$ \\ ${ }^{1}$ Jurusan Akuntansi Fakultas Bisnis, Universitas Katolik Widya Mandala Surabaya \\ Email: budianto@ukwms.ac.id \\ ${ }^{2}$ Jurusan Manajemen Fakultas Bisnis, Universitas Katolik Widya Mandala Surabaya \\ Email: juliusnagel@ymail.com
}

\begin{abstract}
ABSTRAK
Suatu negara perlu memperhatikan tingkat kemakmuran bangsanya, sebab dengan demikian maka negara tersebut akan mengalami banyak kemajuan dalam tingkat kesejahteraan masyarakatnya. masyarakat. Dari hal tersebut dapat dikatakan bahwa peranan mencetak wirausaha sangat memiliki potensi untuk dikembangkan. Jadi generasi penerus bangsa perlu dikembangkan Indonesia mempunyai cita-cita dalam mencapai keadilan bagi masyarakatnya, sehingga cita-cita ini harus diterjemahkan dalam visi dan misi yang ada. Dalam banyak tulisan baik dalam surat kabar maupun penelitian, masalah perekonomian sering mendapatkan sorotan. Usaha Kecil Menengah adalah salah satu bentuk upaya pemerintah dalam menciptakan lapangan kerja guna mencapai tingkat kesejahteraan menjadi entrepreneur, yang mana dapat ditempuh melalui jalur pendidikan tinggi, yaitu adanya mata kuliah kewirausahaan. Prestasi wirausahawan tentu perlu disimak pula. Pendidikan kewirausahaan di Indonesia masih kurang memperoleh perhatian yang cukup memadai, baik oleh dunia pendidikan maupun masyarakat. Banyak pendidik yang kurang memperhatikan penumbuhan karakter dan perilaku wirausaha peserta didik, baik di sekolah-sekolah kejuruan, maupun di pendidikan profesional. Orientasi mereka, pada umumnya hanya pada menyiapkan tenaga kerja. Untuk itu, perlu dicari penyelesaiannya, bagaimana pendidikan dapat berperan untuk mengubah manusia menjadi manusia yang memiliki karakter dan atau perilaku wirausaha.Banyak penelitian mengungkapkan bahwa peranan literasi keuangan khususnya akuntansi sangat lemah, padahal pelaporan Untuk pengembangan modal usaha, perluasan produksi tentu membutuhkan dana tambahan, yang dapat diupayakan melalui ekonomi dari hasil usaha adalah mutlak diperlukan. kredit usaha misalnya perbankan. Tentu pengajuan pengembangan usaha ini harus dilampiri laporan akuntansi, sekalipun sangat sederhana, sehingga bisa dipakai oleh para penyalur kredit dalam pengambilan keputusannya. Kata kunci : literasi akuntansi, kewirausahaan, pendidikan, pembangunan ekonomi
\end{abstract}

\section{PENDAHULUAN}

\subsection{Tujuan Pembangunan Berkelanjutan}

TPB atau Sustainable Development Goals (SDGs) adalah hasil kesepakatan anggota PBB melaksanakan pola pembangunan, mencakup pilar pembangunan sosial, ekonomi, lingkungan, hukum, dan tata kelola. Pilar pembangunan sosial dengan lima tujuan: tanpa kemiskinan; tanpa kelaparan; kehidupan sehat dan sejahtera; pendidikan berkualitas; kesetaraan gender. Pilar pembangunan ekonomi juga dengan lima tujuan: energi bersih dan terjangkau; pekerjaan layak dan pertumbuhan ekonomi, industri, inovasi, dan infrastruktur; berkurangnya kesenjangan; serta kemitraan untuk mencapai tujuan. Sementara di bidang lingkungan, tampil dengan enam tujuan, yakni air bersih dan sanitasi layak; kota dan pemukiman berkelanjutan; konsumsi dan produksi berkelanjutan; penanganan dan perubahan iklim; ekosistem lautan; dan ekosistem daratan. Tujuan- 
tujuan pembangunan berkelanjutan tersebut tentu saja mesti ditopang oleh pilar pembangunan hukum dan tata kelola dengan "kemitraan untuk mencapai tujuan" (Arti, 2018).

\subsection{Peran Mahasiswa Dalam Pembangunan Ekonomi Bangsa Mahasiswa Berwirausaha}

Peranan mahasiswa menjadi sangat penting karena mahasiswa adalah kelompok yang idealis yang terlepas dari pengaruh pihak manapun. Idealisme yang dimiliki mahasiswa membuatnya semangat melakukan perjuangan terhadap kebenaran yang dia yakini. Mahasiswa tidak pantang menyerah dan tidak takut terhadap apapun termasuk presiden sekalipun di dalam menyampaikan aspirasi yang mereka miliki. Pandangan, pemikiran dan sikap mahasiswa inilah yang dibutuhkan dalam mewujudkan Indonesia yang progresif dan inovatif.

Dan perlu kita ketahui bahwa tingkat perekonomian di Indonesia dari tahun ke tahun semakin meningkat. Usaha pemerintah dalam memberantas kemiskinan kini mulai menuai hasil. Berbagai usaha yang dilakukan salah satunya adalah membuat beberapa program yang mendukung masyarakat dalam berwirausaha. Tujuan dari program tersebut untuk mendorong masyarakat khususnya para generasi muda agar lebih produktif dalam mengolah Sumber Daya Alam (SDA) dan membuka lapangan kerja sendiri.

Sebagai contoh program pemerintah yang paling popular adalah Gerakan Kewirausahaan Nasional (GKN) yang mulai dirintis pada tahun 2011. Program tersebut adalah bentuk keperdulian pemerintah baik terhadap perkembangan usaha yang telah berjalan ataupun bagi pemula wirausaha. Program GKN biasanya diperuntukkan bagi mahasiswa atau alumni dari berbagai perguruan tinggi di Indonesia. Tentu akan menjadi suatu kebanggan, ketika seorang mahasiswa sudah memiliki bisnis dan penghasilan sendiri untuk membiayai masa studinya di bangku kuliah. Sehingga, harapan pemerintah terhadap generasi muda dalam menciptakan lapangan pekerjaan akan terealisasi.

Pendidikan kewirausahaan di Indonesia masih kurang memperoleh perhatian yang cukup memadai, baik oleh dunia pendidikan maupun masyarakat. Banyak pendidik yang kurang memperhatikan penumbuhan karakter dan perilaku wirausaha peserta didik, baik di sekolah-sekolah kejuruan, maupun di pendidikan profesional. Orientasi mereka, pada umumnya hanya pada menyiapkan tenaga kerja. Untuk itu, perlu dicari penyelesaiannya, bagaimana pendidikan dapat berperan untuk mengubah manusia menjadi manusia yang memiliki karakter dan atau perilaku wirausaha (Kholifah, N., dan Nurtanto, 2016).

Pendidikan Kewirausahaan. Pendidikan merupakan usaha yang dilakukan secara sadar untuk mengubah tingkah laku seseorang. Kegiatan pendidikan dirancang, diatur, dimonitor dan dievaluasi agar mampu mencapai tujuan yang telah ditentukan. Manusia memiliki berbagai potensi yang dapat dikembangkan melalui pendidikan.

Kewirausahaan merupakan semangat, sikap, perilaku dan kemampuan seseorang dalam menangani kegiatan yang mengarah pada upaya mencari, menciptakan dan menerapkan cara kerja, teknologi dan produk baru secara efisiensi guna memberikan pelayanan yang lebih baik atau memperoleh keuntungan yang lebih besar. Kegiatan kewirausahaan merupakan semangat dan sikap seseorang dalam menangani kegiatan usaha dengan berlandaskan ciri dan watak wirausahawan yang handal (Sukidjo, 2012)

\section{PEMBAHASAN}

(Nagel, 2016) "Pendidikan itu transformasi; mengubah dari yang tak tahu menjadi tahu, dari apolitis menjadi politis," katanya. "Dalam paradigma transformatif, pendidikan menumbuhkan kepedulian sosial.". Entrepreneurship bukanlah sekadar pengetauan, tapi lebih sebagai keterampilan dan seni. Bagaimanakah kemampuan dalam berwirausaha dibangun?. Ia tidak bisa dipelajari hanya secara kognitif di dalam kelas, tapi juga harus dialami (afektif) dan dilakukan (psyco motoric). 


\subsection{Pendidikan Harus Ubah Persepsi Kewirausahaan.}

Wirausahan di Indonesia baru 0,18 persen. Pendidikan di Indonesia harus mampu mengubah cara pandang yang semula bekerja sebagai pegawai, menjadi wirausaha. Perubahan ini harus ditanamkan sejak anak-anak memasuki sekolah tigkat taman kanak-kanak. Soal pendidikan ini, Ketua Himpunan Pengusaha Muda Indonesia (Hipmi) Erwin Aksa berpendapat, kesempatan harus lebih banyak diberikan kepada generasi muda menjadi wirausaha. Direktur Utama PT Bank Mandiri Tbk. Zulkifli Zaini secara terpisah memaparkan, pihaknya menggandeng 600 perguruan tinggi di Indonesia melakukan pelatihan untuk menumbuhkan sikap kewirausahaan (Nagel, 2016).

Bagaimana pendidikan dapat berperan untuk mengubah manusia menjadi manusia yang memiliki karakter dan atau perilaku wirausaha? Untuk mencapai hal tersebut bekal apa yang perlu diberikan kepada peserta didik agar memiliki karakter dan atau perilaku wirausaha yang tangguh, sehingga nantinya akan dapat menjadi manusia yang jika bekerja di kantor akan akan menjadi tenaga kerja yang mandiri kerja dan jika tidak bekerja di kantor akan menjadi manusia yang mampu menciptakan lapangan perkerjaan minimal bagi dirinya sendiri.

Para entrepreneur merupakan pengambil risiko yang telah diperhitungkan agar hasil yang diperoleh lebih besar daripada kegagalan dan sangat bergairah menghadapi tantangan. Adapun sikap dalam menghadapi risiko, antara lain: (1) penghindar risiko, (2) netral, dan (3) penggemar risiko. Dengan jiwa entrepreneurship maka ketakutan akan risiko, tantangan dan hambatan akan bisa di atasi, dan mempunyai motivasi untuk menghasilkan yang terbaik. Selain itu seorang entrepreneur juga harus memiliki kemampuan dalam berkomunikasi sehingga bisa menjalin hubungan dengan konsumen, kelompok lain maupun pemerintah. Masyarakat yang dari lahir bukan keturunan pengusaha, jika memutuskan menjadi entrepreneur maka akan bisa menjadi entrepreneur melalui pelatihan maupun pendidikan tentang entrepreneurship.

\subsection{Menuju Masyarakat Ekonomi ASEAN (MEA).}

SDM merupakan hal yang sangat penting sebagai pelaku dalam MEA. SDM yang berkualitas akan mampu bersaing dan kuat menghadapi tantangan. Cekatan serta inovatif dalam mengambil ide, langkah, dan tindakan. Peningkatan kualitas SDM misalnya dengan pelatihan bahasa, pengembangan skill dapat dilakukan dengan pelatihan, workshop, pertemuan rutin antar pelaku ekonomi, juga pembangunan networking (Kholifah, N., dan Nurtanto, 2016).

Menurut Suryana ciri kewirausahaan yang merupakan nilai hakiki yang penting meliputi (a) percaya diri; (b) berorientasi tugas dan hasil; (c) keberanian mengambil risiko; (d) kepemimpinan; (e) berorientasi ke masa depan; dan (f) keorisinilan: kreativitas dan keinovasian (Sukidjo, 2012). Menurut Hutomo pemberdayaan ekonomi masyarakat adalah penguatan pemilikan faktor-faktor produksi, penguatan penguasaan distribusi dan pemasaran, penguatan untuk mendapatkan gaji/upah yang memadai, penguatan untuk memperoleh informasi, pengetahuan dan keterampilan, yang harus dilakukan secara multi aspek, baik dari aspek masyarakatnya sendiri maupun aspek kebijakannya. Program pemberdayaan yang dilakukan berupa kegiatan penciptaan iklim usaha, penguatan potensi, perlindungan serta pendampingan (Sukidjo, 2012). Program pemberdayaan hendaknya dilengkapi dengan pendidikan kewirausahaan guna menumbuhkan sikap mental dan watak kewirausahaan.

Wirausahawan mempunyai peran yang sangat tinggi dalam melakukan wirausaha. Peran wirausaha dalam perekonomian negara yaitu; 1) menciptakan lapangan kerja, 2) mengurangi pengangguran, 3) meningkatkan pendapatan masyarakat 4) mengombinasikan faktor-faktor produksi (alam, tenaga kerja, modal dan keahlian), 5) meningkatkan produktivitas nasional

Pembangunan ekonomi merupakan sebuah proses yang menyebabkan pendapatan perkapita masyarakat meningkat. Faktor-faktor yang mempengaruhi pembangunan ekonomi negara yang sedang berkembang. Tujuan dalam pembangunan ekonomi ialah sebagai peningkatan pendapatan nasional dan produktivitas. Faktor yang mempengaruhi hal tersebut dalam negara-negara berkembang ialah; 1 ) modal (capital), 2) tenaga kerja yang tersedia, 3) kekayaan alam (sumber daya 
alam) riil, 4) teknologi dan wirausaha, 5) karakteristik sosial budaya masyarakat, 6) luasnya pasar, 7) istem perekonomian yang digunakan.

Peran pendidikan dalam pembangunan nasional antara lain: 1) Mengembangkan teknologi. Hasil pendidikan adalah orang terdidik yang mempunyai kemampuan melaksanakan penelitian dan pengembangan yang dapat menghasilkan teknologi baru. 2) Menjadi tenaga produktif dalam bidang konstruksi. Orang-orang terdidik hasil pendidikan bisa masuk dan aktif bekerja di bidang konstruksi bangunan baik pabrik maupun perusahaan. Dimana dari pabrik dan perusahaan inilah akan dihasilkan berbagai kebutuhan hidup. 3) Menjadi tenaga produktif yang menghasilkan barang dan jasa. Orangorang terdidik hasil pendidikan juga memiliki keterampilan untuk menghasilkan barang dan jasa. Mereka bisa menjadi karyawan di sebuah pabrik atau perusahaan dan mengandalkan skill mereka masing-masing. 4) Pelaku generasi dan penciptaan budaya. Orang-orang terdidik hasil pendidikan menjadi pelaku yang memahami betul generasi yang dijalaninya untuk kemudian diperbaiki sesuai perkembangan zaman, dengan tetap mendasarkan pada budaya lama yang dimilikinya. 5) Konsumen barang dan jasa. Menjadi generasi yang mengkonsumsi barang dan jasa yang dihasilkan dengan jenis keperluan yang bervariasi dan lebih banyak. Mereka lebih kritis dalam menggunakan barang dan jasa, apabila dibandingkan dengan orang yang kurang terdidik.

Peranan pendidikan dalam pembangunan nasional dapat dilihat dalam gambar di bawah ini:

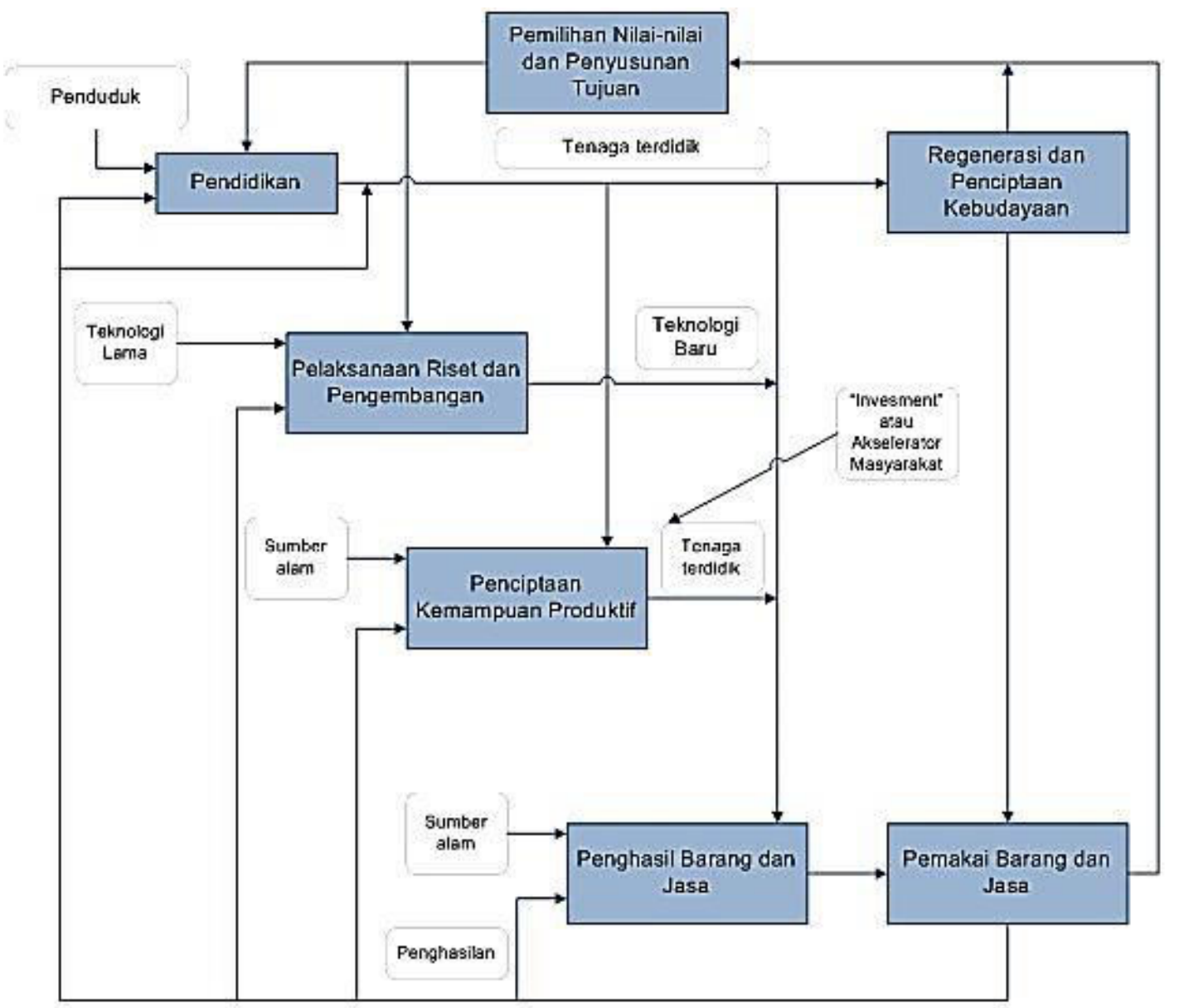

Sumber: Redja Mudyaharjo (2010) dalam ekonomi.sobatmateri.com (2018)

Gambar Peranan Pendidikan dalam Pembangunan Nasional

Adapun peran wirausaha dalam perekonomian di negara kita adalah: 1) Menciptakan lapangan pekerjaan. Pengangguran disebabkan tidak seimbangnya kenaikan angkatan kerja dengan lapangan kerja yang disediakan pemerintah atau swasta. Wirausaha yang ada mampu membantu menyerap pengangguran sebab adanya wirausaha berarti lapangan kerja baru dibuka atau muncul. 2) 
Meningkatkan pendapatan nasional. Inovasi yang dilakukan para wirausaha menyebabkan jumlah permintaan naik dan diikuti dengan naiknya jumlah produksi barang. Kenaikan jumlah permintaan dan produksi ini mampu meningkatkan pendapatan nasional negara. 3) Meningkatkan taraf hidup masyarakat. Wirausaha adalah seseorang yang mampu menciptakan lapangan pekerjaan. Mereka mampu menyerap pengangguran terutama di sekitar wilayah mereka. Secara langsung taraf kehidupan masyarakat sekitar dapat meningkat sebab mereka telah memperoleh pendapatan dari bekerja pada wirausaha tersebut. Sehingga dapat kita simpulkan bahwa wirausaha mempunyai peranan penting di dalam kehidupan ekonomi untuk meningkatkan taraf hidup masyarakat. 4) Mengurangi kesenjangan ekonomi dan sosial. Masyarakat yang mampu menjadi wirausaha mampu mendapatkan penghasilan sehingga sedikit demi sedikit pendapatan mereka bertambah. Hal ini menyebab-kan kesenjangan sosial yang ada di masyarakat dapat dikurangi.

Sedangkan manfaat adanya para wirausaha, adalah sebagai berikut; 1 ) memperbesar tingkat kesempatan kerja, sehingga dapat mengurangi pengangguran, 2) berusaha memberi bantuan kepada orang lain dan pembangunan sosial, sesuai dengan kemampuannya, 3) memberi contoh bagaimana harus bekerja keras, tekun, tetap tidak melupakan perintah agama, 4) menjadi contoh bagi anggota masyarakat sebagai pribadi unggul yang patut diteladani, 5) sebagai generator pembangunan lingkungan, pribadi, distribusi, pemeliharaan lingkungan dan kesejahteraan, 6) berusaha mendidik para karyawannya menjadi orang yang mandiri, disiplin, tekun dan jujur dalam menghadapi pekerjaan.

Akuntansi seni pencatatan, pengelompokkan dan pengikhtisaran menurut cara-cara yang berarti dan dinyatakan dalam nilai uang, segala transaksi keuangan dan kemudian menafsirkan artinya (American Institute of Certified Public Accounts, AICPA). Akuntansi merupakan teknologi, dan oleh karenanya pengembangan tehnologi akuntansi keuangan yang ada nantinya merupakan rekayasa informasi dan pengendalian keuangan. Dari pengertian tersebut dapat disimpulkan bahwa laporan akuntansi adalah produk akhir dari suatu prestasi kinerja, yang dicantumkan dalam bentuk angka. dengan demikian para pemilik usaha perlu menyusun laporan akuntansi agar dapat memberikan informasi terhadap langkah langkah yang harus diambil sehubungan dengan capaian kinerja yang sudah dilakukan.

Adapun penyusunan laporan keuangan yang ada biasanya mencakup laporan neraca, laporan rugi laba, laporan perubahan modal pemilik, yang mana secara sederhana minimal laporan ketiga hal terbut harus disusun oleh pemilik usaha. Adanya penyusunan laporan akuntansi dapat menguntungkan beberapa hal misalnya, dapat dipakai untuk pengajuan kredit di bank, dapat dipakai sebagai acuan untuk penambahan kredit usaha bagi para kreditur, dapat menarik minat investor untuk bergabung menjadi perusahaan yang lebih besar, untuk kepentingan perpajakan negara.

Laporan Laba Rugi: laporan yang menunjukkan kemamnpuan perusahaan menghasilkan laba selama satu periode akuntansi atau se tahun. Isinya pendapatan yang ada setelah dikurangi beban beban maka diperoleh laba. Laporan Perubahan Ekuitas: laporan yang menunjukkan perubahan hak residu atas asset perusahaan setelah dikurangi semua kewajiban. Laporan Arus Kas: laporan yang menunjukkan aliran uang yang diterima dan yang digunakan perusahaan selama satu periode akuntansi beserta sumber-sumbernya. Pada umumnya dikelompokkan sebagai aktivitas operaasi, aktivitas Investasi dan aktivitas pendanaan.

Kualitas Laporan Keuangan: Bidang usaha yang karakteristik tertentu memiliki laporan keuangan yang tertentu pula, namun ada beberapa hal inti yang dapat dipandang sebagai kualitas laporan yaitu; 1. Dapat Dipahami. Pengguna diasumsikan memiliki pengetahuan minimal untuk dapat memahami laporan yang berisi aktivitas ekonomi dan bisnis serta akuntansi dan pemahaman tentang informasi dengan penuh seksama, 2. Relevan. Infomasi yang ada adaklah relevan, dengan kebutuhan perngguna, untuk proses pengambilan keputusan, dengan melakukan evaluasi atas masa lalu, sekarang dan peramalan masa depan, 3.Materialitas. Sifat kelalaian yang bersifat signifikan, sehingga dapat mempengaruhi keputusan ekonomi pengguna yang diambil atas dasar laporan keuangan. Pos yang bersifat material dalam penyajian laporan keuangan dapat mempengaruhi 
pengambilan keputusan, 4. Keandalan. Kualitas informasi yang andal mempunyai arti bahwa bebas dari kesalahan material dan bisa serta disajikan secara wajar, 5. Dapat Dibandingkan. Pengguna harus dapat membandingkan laporan antar entitas, dengan harapan dapat mengambil langkah2-langkah untuk kemajuan usahanya, 6 . Tepat Waktu. Pengertian ini berarti mencakup penyediaan informasi laporan dalam jangka waktu pengambilan keputusan.

Tujuan penyusunan laporan keuangan: 1) Memberikan informasi keuangan yang dapat dipercaya atas sumber ekonomi dan kewajiban serta modal perusahaan. 2) Memberikan informasi yang dapat dipercaya atas perubahan sumber daya ekonomi yang timbul dalam aktivitas usaha 3) Membantu para pengguna aporan untuk melakukan estimasi potensi dimasa depan. Dengan melihat tujuan umum kegunaan laporan keuangan yang sangat baik bagi para pengguna laporan tersbut, ternyata memiliki kendala bagi kebanyakan para wirausahawan Pentingnya literasi akuntansi bagi beberapa kelompok usaha kecil dan menengah telah dilakukan penelitian. Astuti menyatakan bahwa dalam hasil penelitiannya di Kabupaten Kudus ditemukan penggunaan informasi akuntansi pada perusahaan kecil dan menengah sangat rendah (Astuti, 2007).

Wahyudi dalam hasil risetnya menemukan bahwa faktor pemilik usaha dan skala usaha ternyata mempunyai pengaruh terhadap penggunaan informasi akuntansi baik pada usaha kecil maupun usaha menengah (Wahyudi, 2009).

Dalam hasil risetnya Ernawati menyatakan bahwa minimnya penerapan sistem akuntansi yang dilakukan oleh usaha kecil dan menengah untuk melakukan pencatatan atau pembukuan usaha disebabkan pertimbangan kerepotan dalam upaya penyajiannya (Ernawati, S., Asyikin, J., Sari, 2016).

\section{KESIMPULAN}

Peranan literasi keuangan khususnya akuntansi sangat lemah, padahal pelaporan ekonomi dari hasil usaha adalah mutlak diperlukan. Untuk pengembangan modal usaha, perluasan produksi tentu membutuhkan dana tambahan, yang dapat diupayakan melalui kredit usaha misalnya perbankan. Program pemberdayaan hendaknya dilengkapi dengan pendidikan kewirausahaan guna menumbuhkan sikap mental dan watak kewirausahaan. Tingkat perekonomian di Indonesia dari tahun ke tahun semakin meningkat. Usaha pemerintah dalam memberantas kemiskinan kini mulai menuai hasil. Berbagai usaha yang dilakukan salah satunya adalah membuat beberapa program yang mendukung masyarakat dalam berwirausaha. Tujuan dari program tersebut untuk mendorong masyarakat khususnya para generasi muda agar lebih produktif dalam mengolah Sumber Daya Alam (SDA) dan membuka lapangan kerja sendiri. Sebagai contoh program pemerintah yang paling popular adalah Gerakan Kewirausahaan Nasional (GKN) yang mulai dirintis pada tahun 2011. Wirausahawan mempunyai peran yang sangat tinggi dalam melakukan wirausaha. Peran wirausaha dalam perekonomian negara yaitu; 1) menciptakan lapangan kerja, 2) mengurangi pengangguran, 3) meningkatkan pendapatan masyarakat 4) mengombinasikan faktor-faktor produksi (alam, tenaga kerja, modal dan keahlian), 5) meningkatkan produktivitas nasional

\section{DAFTAR PUSTAKA}

Arti, Y. (2018). Peran Mahasiswa dalam Pembangunan Ekonomi Bangsa Mahasiswa Berwirausaha. Retrieved June 24, 2018, from https://www.kompasiana.com/yuniarti1207/5b01a5625e1373539107ffd5/peran-mahasiswadalam-pembangunan-ekonomi-bangsa-mahasiswa-berwirausaha

Astuti, E. (2007). Pengaruh Karakteristik Internal Perusahaan Terhadap Penyiapan dan Penggunaan Informasi Akuntansi Perusaahaan Kecil dan Menengah di Kabupaten Kudus. Universitas Diponegoro, Semarang.

Ernawati, S., Asyikin, J., Sari, O. (2016). Penerapan Sistem Akuntansi Dasar pada Usaha Kecil Menengah di Kota Banjarmasin. Jurnal Penelitian IImi Ekonomi WIGA, 6(2), 81-91.

Kholifah, N., dan Nurtanto, M. (2016). Pengembangan Pendidikan Kewirausahaan Dalam 
Menanamkan Nilai-Nilai Entrepreneurship Untuk Menghadapi Masyarakat Ekonomi ASEAN (MEA). In Prosiding Seminar Nasional Inovasi Pendidikan: Inovasi Pembelajaran Berbasis Karakter dalam Menghadapi Masyarakat Ekonomi ASEAN (pp. 411-418).

Nagel, P. J. F. (2016). Tantangan Pendidikan Kewirausahaan di Perguruan Tinggi Pada Era Global. In Capita Selecta Seputar Kewirausahaan (pp. 147-152).

Sukidjo. (2012). Peran Pendidikan Kewirausahaan dalam Pemberdayaan Masyarakat Miskin di Indonesia. Jurnal Economia, 1(8), 33-41.

Wahyudi, M. (2009). Analisis Faktor-Faktor yang Mempengaruhi Penggunaan Informasi Akuntansi Pada Usaha Kecil dan Menengah (UKM) di Yogjakarta. Universitas Diponegoro, Semarang. 